https://doi.org/10.22363/2312-8674-2019-18-3-699-709

Рецензия / Book Review

Бранденбергер Д. Кризис сталинского агитпропа: пропаганда, политпросвещение и террор в СССР, 1927-1941 / пер. с англ. А.А. Пешкова, Е.С. Володиной. М.: Политическая энциклопедия, 2017. 367 с. (Серия «История сталинизма»)

Н.Г. Георгиева (рецензент)

Российский университет дружбы народов;

117198, Россия, Москва, ул. Миклухо-Маклая, 6; navladi@list.ru

\title{
Brandenberger, David L. Krizis stalinskogo agitpropa: propaganda, politprosveshcheniye i terror v SSSR, 1927-1941 [Crisis of Stalin's agitprop: propaganda, political education and terror in the USSR, 1927-1941]. Moscow: Politicheskaya encyclopedia Publ., 2017., 367 p.
}

\author{
Natalia G. Georgieva (reviewer) \\ Peoples' Friendship University of Russia (RUDN University); \\ 6 Miklukho-Maklaya St., Moscow, 117198, Russia; navladi@list.ru
}

Первоначальная публикация монографии Дэвида Бранденбергера, доктора исторических наук, профессора, хорошо известного и в США, и в нашей стране русиста, была осуществлена на английском языке в 2011 г. в издательстве Йельского университета (США) 1 . Рецензируемое издание вышло на русском языке в 2017 г. при финансовой поддержке фонда «Историческая память» в серии «История сталинизма». Д. Бранденбергер входит в круг тех американских специалистов, которые выступают против свертывания Государственным департаментом США программы исследований истории СССР. Они считают, что изучение истории политики и культуры советской страны необходимо не только в силу познавательных, но и практических соображений, так как современные западные политики и дипломаты должны обладать верифицированной информацией, содержащей объективную картину советского прошлого и академически выверенные, социальнополитические рекомендации, направляющие их деятельность на пространстве бывшего СССР.

(C) Георгиева Н.Г., 2018

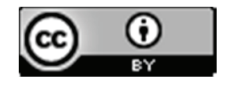

This work is licensed under a Creative Commons Attribution 4.0 International License https://creativecommons.org/licenses/by/4.0/

${ }^{1}$ David Brandenberger, Propaganda state in crisis Soviet ideology, indoctrination, and terror under Stalin, 1927-1941 (New Haven and London: Yale University Press, 2011). 
Д. Бранденбергер поставил цель - исследовать деятельность идеологического аппарата ВКП(б), которому, по его словам, долгое время «не уделяли должного внимания» в историографии (С. 16). Главная идея автора состоит в том, что созданный еще при И.В. Сталине механизм устной и печатной пропаганды, использованный в дальнейшем и КПСС, не добился успеха в воспитании советского общества в духе марксизма-ленинизма и в идейной мобилизации масс на строительство социализма ни в 1920-1930-х гг., ни в последующий период.

Для объяснения провала деятельности («кризиса») сталинского агитпропа в книге выстроена система доказательств, опирающаяся на изучение истории его становления и эволюции в довоенном СССР.

В центре внимания автора «сталинизм»- устойчивый, сложившийся в международном научном информационном пространстве конструкт, вызывающий острый гносеологический интерес не только среди профессиональных историков, но и политиков, социологов и публицистов. Вокруг него более полувека рождаются различные идейные концепции, в одних случаях имеющие академический характер, опирающийся на доказательную источниково-информационную основу, в других - исключительно публицистический, обусловленный социально-политическим заказом, часто вызванным ненавистью к большевизму и России, ее властным структурам и народу. Сразу же отметим, что в рецензируемой монографии все наблюдения и выводы автора выстраиваются на информации, почерпнутой в опубликованных материалах и документах, хранящихся в 17 российских архивах.

Подкупает и историографическая составляющая, дискуссионность книги: автор не только широко использовал наблюдения и выводы отечественных и зарубежных историков, но и не редко вступал с ними в спор. В этом плане особый интерес представляют обширные примечания, в которые автор, чтобы не нарушать логику и последовательность изложения событий, выносил свои возражения по поводу того или иного суждения, имеющегося в литературе.

В историографической справке Д. Бранденбергер определил шесть групп исследователей, по-разному оценивавших идейно-политические воззрения Сталина и его окружения, приверженность партийных лидеров и их готовность следовать марксистско-ленинской парадигме. Автор книги пришел к выводу о том, что идеологические перемены не означали отказа партийного руководства 1930-х гг. от идей, провозглашенных Октябрьской революцией (С. 12). Д. Бранденбергер присоединился к мнению американского исследователя С. Коткина, рассматривавшего эти перемены в контексте «стратегического перехода от задачи строительства социализма к задаче защиты социализма».

Отметим, что идеи С. Коткина и Д. Бранденбергера явно недостаточны для объяснения стратегических целей и идеологии партийного руководства страны, которое даже (и особенно) в условиях капиталистического окружения сохраняло курс на строительство социализма (одновременно и несмотря на культ личности Сталина, диктатуру аппарата ВКП(б), усиление массовых необоснованных политических репрессий), а во второй половине 1930-х гг. взяло курс на завершение строительства социализма и (утопическая цель) постепенный переход к коммунизму, провозглашенный на XVIII съезде ВКП(б). Тем не менее попытка еще одного (оригинально- 
го) объяснения причин, по которым деятельность агитпропа не имела успеха, вполне заслуживает внимания отечественной научной общественности.

Свою исследовательскую цель автор монографии реализовал в лучших традициях позитивистской методологии, основываясь на известной и чеканной формуле: история пишется по источникам; нет их - нет и истории.

Исследование Д. Бранденбергера опирается на междисциплинарный и социокультурологический подходы, основу реализации которых создали разные виды исторических источников. Для изучения механизма распространения официального идеологического курса использованы сведения делопроизводственной документации центральных и местных партийных и советских органов (ОГПУ, НКВД, РККА, Главлит и др.), а также местных кружков политпросвета. Особое познавательное значение для понимания атмосферы восприятия партийной пропаганды в советском обществе имела информация, подчерпнутая из мемуаров, дневников и писем, оставшихся от современников из разных социальных слоев, публицистических публикаций в периодической печати, популярных художественных произведений деятелей всех сфер культуры и исторических трудов советской научной интеллигенции. Все это позволило автору книги создать целостную картину и идеологической деятельности агитпропа, и отношения к ней широких слоев населения.

В композиции монографии прослеживаются три тематических блока исследовательских задач автора: восстановить процесс формирования сталинского агитпропа; показать его эволюцию и смену механизмов воздействия партийного руководства на общественное сознание; вскрыть и объяснить причины провала попытки воспитания населения в духе марксизма-ленинизма. Параллельно Д. Бранденбергер провел специальный анализ того, как навязываемая идеология воспринималась обычными советскими гражданами на групповом (коллективном) и индивидуальном уровнях.

Содержание первых глав книги: «Первое десятилетие агитпропа», «Поиск “полезного прошлого” партии» и «Персонификация советского “эксперимента”» восстанавливает процесс формирования аппарата агитпропа. Автор показал, что недостаток образованных кадров пропагандистов, неспособность малообразованных пролетариев и крестьян воспринимать схематичное и поверхностное изложение основных понятий марксизма не способствовали успеху классового политического просвещения ни рядовых партийцев, ни широких масс. Изложение истории революции и ее недавнего социально-политического опыта мало помогало становлению сознания нового советского человека как активного защитника завоеваний революции. Упор официальной пропаганды на абстрактные (в понимании народа) принципы: «интернационализм, классовое сознание, союз рабочих и крестьян» как опоры советской власти - имел в середине 1920-х гг. «гораздо меньший социальный резонанс, чем ранее предполагалось» (С. 25). К 10-летнему юбилею революции «ни партия, ни революция, ни идея диктатуры пролетариата... не завоевали особого сочувствия в советском обществе» (С. 31). Объясняя причины провала мобилизационной политики партии, Д. Бранденбергер справедливо ссылается на недостаток образовательной подготовки большой части населения (С. 32). Автор отметил, что руководство ВКП(б) было вынуждено признать, что «в идеологической обработке 
населения реальный прогресс не достигнут» и требуются радикальные перемены в дальнейшем ходе институциональной реформы с акцентом на грамотность, профессионализм и конкретный, практичный подход (С. 30).

Раскрывая меры, которые предприняло партийное руководство для совершенствования официального идеологического курса, Д. Бранденбергер объясняет их, во-первых, практическими задачами индустриализации, коллективизации и идеологической работы (С. 34). Во-вторых, перемены в идеологической обработке масс автор связывает с публикацией в октябре 1931 г. печально известного письма Сталина в редакцию журнала «Пролетарская революция», в котором историки были резко раскритикованы «за неспособность идти в ногу с меняющимися приоритетами» (С. 34). Даже фанатично преданных партийцев (Е.М. Ярославского и др.) Сталин пренебрежительно назвал «архивными крысами» и призвал их «концентрироваться только на героических поступках партийных вождей, обходясь без изучения источников и других “академических” изысков» (С. 35). История, особенно история партии, была поставлена на службу государству. Перед ней в первой половине 1930-х гг. партийное руководство поставило ряд новых требований и новый объем задач, в том числе пересмотр всех учебников по истории партии, реорганизацию партийной образовательной системы, переподготовку агитработников и создание настольных книг, доступных даже самым малообразованным слоям населения. В книге приведены подробности, характеризовавшие процесс создания новых учебников по истории партии, приведены имена участников бригад, созданных в Институте Маркса - Энгельса - Ленина (ИМЭЛ) для написания канонического учебника, то есть, с одной стороны, раскрыты белые пятна в истории партии и ее историографии (С. 37-46). С другой стороны, автор монографии сделал вывод: 1933-1936 гг. стали «полем битвы» за написание действительно популярного учебника по истории партии для системы политпросвета, но «годы усилий дали лишь набор устаревших, бесполезных книг», не способствовавших решительной реформе в идеологическом политпросвете и партийном образовании. Справедливо и наблюдение Д. Бранденбергера о том, что историки партии, перед которыми руководство поставило задачу - искать «героев» среди вождей партии - убедились, что политические карьеры вождей невозможно описать положительными, идеологически выдержанными понятиями. Д. Бранденбергер сделал вывод, что «вожди» сами виноваты в том, что не обеспечили историков четким представлением о том, чего от них ожидают. По мнению автора рецензируемой монографии, «такого рода препятствия необходимо было устранять, если партийное руководство еще хотело найти версию “полезного прошлого”, которая способствовала бы мобилизации масс» (С. 57).

В качестве такой «версии» Д. Бранденбергер рассмотрел «функционирование культа» путем создания официальной биографии Сталина. Изучение процесса построения этой биографии (по мнению автора монографии. - Н.Г.) обеспечивало идеальный ситуационный анализ для оценки харизматических составляющих культа личности (С. 59) и, добавим к этому, для истории складывания официального идеологического курса, а также для истории отечественной исторической науки, так как потенциальные «биографы Сталина... оставили богатый документальный след» (С. 59). Д. Бранденбергер раскрыл сложившуюся в период создания биографии Стали- 
на интригу, в которой участвовали и некоторые члены его окружения (например, Л.П. Берия), и А. Барбюс, член французской компартии, представивший в 1934 г. апологетический текст, изобиловавший фактическими и идеологическими ошибками (издан за рубежом в 1935 г.), и отечественные историки партии. По наблюдению Д. Бранденбергера, «один из самых примечательных аспектов этой истории - масштаб междоусобной борьбы, которая, похоже, происходила за кулисами в идеологическом аппарате» (С. 72). В итоге попытки создать приемлемую официальную биографию вождя провалились и из-за конкуренции возможных биографов, и из-за недостаточной разработанности истории самой партии.

Содержание следующих трех глав книги: «Культ героев и героизма», «Триумфальное шествие советского патриотизма» и «Популярность официального курса» - развивает решение проблем, рассмотренных в первых главах. В них раскрыты настойчивые, но и неудачные, попытки историков создать историю партии, найдя в ней «полезное прошлое» в лице героев революции, и написать биографию Сталина, показав его вождем революции, ее идеологом и главным организатором социалистического строительства.

В этих главах Д. Бранденбергер сделал тщательно документированный вывод: первооткрывателем «полезного прошлого» в отечественной истории и успешным проводником официального идеологического курса стали не члены партийно-пропагандистского аппарата, показавшие свою неспособность выполнить поставленные перед ними задачи, а представители творческой интеллигенции -журналисты, кинематографисты и литераторы. Они прославили имена реальных героев, совершавших военные подвиги в ходе Гражданской войны, новых маршалов, выдвинувшихся в последующих столкновениях с иностранными агрессорами, рабочих и крестьян, достигавших высоких трудовых показателей в процессе социалистического строительства в промышленности, строительстве и сельском хозяйстве, летчиков, спасавших челюскинцев и т.п. (С. 74-125). Главное идеологическое значение этих персонажей состояло в том, что, с одной стороны, это были деятели современности, а не какого-то отдаленного, дореволюционного прошлого, что значительно усиливало мобилизационно-пропагандистский эффект от популяризации их имен. С другой стороны, Д. Бранденбергер, ссылаясь на слова Н.И. Бухарина, отметил новую плеяду героев - людей труда, которые «уничтожают нищету, ломают смрадные очаги, добивают бескультурье»; это герои труда, борьбы и творчества, деятельность которых была понятна, а социальное происхождение близко основной массе населения (С. 99-100).

Большое внимание Д. Бранденбергер справедливо уделил проблеме изменения вектора в пропагандистской компании партийного идеологического аппарата: в сталинских лозунгах к первомайской демонстрации трудящихся в 1934 г. появилось слово «Родина», сменившее абстрактный лозунг «пролетарского интернационализма» и ставшее краеугольным камнем официального партийного лексикона. Это, по мнению автора монографии, стало свидетельством нарождавшегося курса на патриотизм и возникновения нового идеологического понятия - «социалистическое отечество», что было вызвано осложнением международной обстановки, в которой все сильнее проявлялась угроза войны (С. 106-117). Новая мобилизационная 
стратегия, ориентировавшая население СССР на защиту своего социалистического отечества, вызвала мощную поддержку всего советского общества, в активизации которой большую роль сыграла партийная и комсомольская пресса, литература, художественное и документальное киноискусство, обладающие особыми и доступными для широких масс средствами воздействия на групповое общественное сознание (С. 125-127). В соответствии со своей основной идеей о практической слабости и кризисе агитпропа, Д. Бранденбергер подчеркнул, что успех (он использовал слово «триумф») в деле воспитания советского патриотизма, достигнутый творческой интеллигенцией, одновременно являлся одним из показателей снижения влияния историков партии и идеологов из органов агитпропа в 1930-х гг. (С. 103).

Можно согласиться с мнением Д. Бранденбергера о том, что изменение идеологического курса повлекло за собой принятие постановлений о преподавании истории и географии в средней школе; можно принять также и его оценку этих постановлений - они имели, по его словам, «поистине гигантский масштаб, влияя далеко не только на школу» (С. 109).

Справедлив и следующий вывод Д. Бранденбергера: «постановления требовали переноса упора с “социологической” теории на более традиционную государственную интерпретацию русско-советской и всемирной истории, которая должна вернуть чувство гордости и сделать более живым преподавание истории с помощью увлекательных рассказов о легендарных героях и злодеях» (С. 109).

Однако этому сюжету автор посвятил всего один абзац (11 строк), что мало соответствует «гигантскому масштабу» этого государственного акта и, главное, культурологическому значению Постановления СНК СССР и ЦК ВКП(б) от 16 мая 1934 г. (автор не указал даже даты) «О преподавании гражданской истории в школах СССР». Особенно, если сравнивать с другими событиями, о которых написано более пространно (например, о спасении челюскинцев упомянуто несколько раз, см.: с. 108, 126, 128, 158; кинофильму «Чапаев» посвящены с. 92-95, 132-133 и 146; пересказ содержания ленты «Родина зовет» 1936 г. занял полную страницу). И главное, в Постановлении от 16 мая речь шла не только о том, чтобы ученикам на уроках рассказывали «увлекательные рассказы». Оно предусматривало воссоздание исторических факультетов в Московском и Ленинградском университетах, то есть способствовало развитию исторического образования, ставило подготовку новых кадров историков на государственный уровень. На основе этого Постановления (вслед за МГУ и ЛГУ) исторические или историко-филологические факультеты были открыты во многих областных центрах и союзных республиках СССР.

Если содержание четвертой - шестой глав книги связано с анализом постепенных успехов в формировании официального идеологического курса и его победного восприятия в обществе, то в следующих частях («Уничтожение “полезного прошлого”», «Массовая культура в годы террора», «Окостенение официального курса») раскрыты результаты воздействия массового партийно-государственного террора на идеологическую сферу. Этот материал служит еще одним доказательством основной идеи книги - неспособность идейно-пропагандистского партийного аппарата мобилизовать общество и внедрить в массовое общественное сознание идеи марксизма-ленинизма. 
В качестве одной из причин провала идеологической работы ВКП(б) Д. Бранденбергер назвал партийные «чистки», политические процессы и «большой террор», которые «заморозили» общество, напугали и «отгородили» его от властных государственных и партийных структур. Иными словами, было виновато само партийно-государственное руководство - оно оказалось неспособным успешно руководить идеологическим воспитанием общества; оно не смогло предложить органам агитпропа действенных идей и средств, нацеленных на мобилизацию масс и внедрение марксизма-ленинизма в общественное сознание.

Второй причиной, по мнению Д. Бранденбергера, тесно связанной с первой, было уничтожение в ходе репрессивной социальной политики наиболее активной части творческой интеллигенции, обеспечившей кратковременный успех официального идеологического курса в его проникновении в сознание масс.

Третьей причиной, по мысли автора монографии, явились сами историки партии, тратившие силы на конкуренцию и междоусобицы, ждущие от власти спасительных предначертаний, неспособные создать или воспринять новые творческие идеи для преодоления схематизма и догматизма в своем нарративе. К этому добавлялось отсутствие художественных талантов у большинства историков партии: в их научном арсенале не было тех средств, которыми обладали представители творческой интеллигенции, большая часть которой попала под репрессии или была потрясена «развенчанием» вчерашних «героев».

Связывая указанные причины, Д. Бранденбергер высказал предположение: партийное руководство явно рассчитывало, что историки партии возьмут на вооружение новые тенденции, сложившиеся в массовой культуре в результате деятельности представителей творческой интеллигенции, найдут новых «героев», имена которых вдохновят советский народ, создадут научный и популярный труд для нового мобилизационного прорыва. Однако эти ожидания были напрасны.

Д. Бранденбергер справедливо считает, что препятствием для написания нового и понятного массам учебника по истории ВКП(б), который должен был стать основой для идеологической пропаганды и сети политпросвещения, явились три главные трудности: 1) как изображать В.И. Ленина (в строгой исторической достоверности или дать художественную интерпретацию образа вождя); 2) отсутствие всеобъемлющей биографии Сталина; 3) волна арестов, превращавшая литературу в постоянно пополняемый мартиролог (С. 154-159, 162-163). По оценке Д. Бранденбергера, «едва ли не единственным проектом, сорванным террором», стал текст по истории партии (С. 158).

Заметим, что в приведенной оценке отсутствует уточнение о том, что автор подразумевал только историко-партийную сферу. Без такого уточнения фраза содержит явное преувеличение: террор похоронил (в прямом и переносном смыслах) множество исследовательских проектов в других областях научной деятельности.

Всего одну страницу (непропорционально мало по сравнению с анализом других событий в художественной жизни страны) автор посвятил рассказу об истории творческого конкурса к 20-летнему юбилею Октябрьской революции, для участия в котором было приглашено девять драматургов и десять сценаристов. Им поручалось создать к юбилею новые работы для театра и кино. Однако, 
как выяснил автор книги, «только один сценарий и четыре пьесы оказались хоть в какой-то степени приемлемыми, причем две пьесы потребовали серьезных переделок перед их окончательным утверждением. Единственным очевидным триумфом конкурса стал сценарий А.Я. Каплера “Ленин в Октябре", по которому М.И. Ромм спешно снял фильм летом 1937 г.» (С. 159). Д. Бранденбергер, ссылаясь на мнение К. Петроне, отметил, что авторы фильма «обошли» острые углы, изобразив Ленина источником морального авторитета, опирающегося на Сталина как на организатора революции, мудрого и всезнающего вождя (С. 159-160) .

Исследуя влияние массового террора на систему партпросвещения в 19361938 гг., Д. Бранденбергер пришел к выводу, что ежовщина резко затормозила ее развитие, особенно на низовом уровне - среди рядовых членов партии, комсомольцев и бойцов Красной Армии (С. 166, 183). Чистка «пантеона» советских героев не позволяла активистам использовать известные имена партийных вождей, военачальников и гражданских лиц для демонстрации таких основополагающих советских ценностей, как героизм и патриотизм, что, в свою очередь, не могло укрепить реализацию цели агитпропа, состоявшей в закреплении позитивного восприятия советской действительности в сознании масс (С. 183). Д. Бранденбергер на основе анализа информации эпистолярия, дневников и делопроизводственных сводок органов госбезопасности получил, по его словам, «жуткую картину того, что ежовщина сделала с общественным мнением в СССР в 1936-1938 гг.» (с. 185-186). Оно раскололось, утрачивая воспитанное ранее советское единство и веру в идеалы социализма. Одни - свято доверяли всем сообщениям прессы о разоблачении предателей и вредителей. Вторые - не верили и критически оценивали эти сообщения, сомневаясь (и самостоятельно, и под влиянием политически трезво думающих друзей и родных) в таком большом количестве «врагов народа». Третьи - узнав об арестах представителей советского Олимпа, разочаровывались в партийно-советском руководстве, что приводило к социальной паранойе и социальной апатии (С. 185-200).

В указанных главах Д. Бранденбергер пришел к выводу, что уничтожение партийным руководством собственного «полезного прошлого» в 1936-1938 гг. «подорвало доверие к нему значительной части советского общества» и фактически стало наглядным свидетельством кризиса агитпропа (С. 201).

Завершению процесса создания учебника по истории партии в 1937-1938 гг. и проблемам восприятия его текста в обществе в предвоенный период Д. Бранденбергер посвятил значительную часть своей монографии. Особый интерес для современного читателя представляет его исследование сталинских редакционных правок, помещенное не только в основном тексте, но и в примечаниях. Автор монографии раскрыл подробности, характеризовавшие процесс корректуры текста Сталиным, вступая в дискуссии с некоторыми его биографами.

Д. Бранденбергер отметил, что новый вариант рукописи - «История ВКП(б). Краткий учебник» - был представлен Сталину на пике политики «большого террора». Это был результат труда Е.М. Ярославского, П.Н. Поспелова и группы их помощников из ИМЭЛ, работавших над книгой с осени 1937 г.

Сталин передал рукопись наиболее приближенным соратникам, сам приступил к редактированию текста введения к учебнику и дал рекомендации, направ- 
ленные на изменение содержания ключевых аспектов в ряде частей книги. Затем он сам переписал основные разделы учебника, обращая особое внимание на вопросы истории борьбы с оппозицией в партии. Так, по наблюдениям Д. Бранденбергера, началась практическая работа над долгожданным учебником по истории партии. В итоговой версии в название текста было внесено изменение - «История ВКП(б). Краткий курс». В итоге редактирования Сталин переделал 11 глав из 12, усиливая теоретические аспекты истории партии «ввиду слабости наших кадров, по его словам, в области теории» (С. 202-205).

Сталин, по наблюдению Д. Бранденбергера, осуществил «системный пересмотр исторического нарратива». Он вырезал из рукописи целые страницы и десятки разделов для того, чтобы убрать перегруженность текста «незначительными историческими деталями», в том числе и имевшими «отношение к его собственной карьере» (С. 206). По мнению Д. Бранденбергера, сталинская редактура - чистка «Краткого курса» - стала «последним из главных проявлений политического насилия в эпоху ежовщины, ознаменовавшим окончание поиска “полезного прошлого”» (С. 210).

Вышедший осенью 1938 г. «Краткий курс», по первым отзывам современников, имел концептуальную значимость как энциклопедия марксизма-ленинизма и незаменимое руководство по овладению большевизмом, оказав, по оценке Д. Бранденбергера, «огромное влияние на советскую пропаганду» (С. 211, 214). Агитаторы, которые ожидали официального учебника с начала 1930-х гг,, особенно были довольны структурированностью изложения истории революционного и послереволюционного периодов. Однако схематичность и предельно краткие формулировки важнейших теоретических и конкретно-исторических положений вызвали необходимость публикации пособий, дополняющих и развивающих текст учебника (С. 214-215).

По завершении создания учебника вновь возникла идея написания биографии Сталина, подхваченная группой сотрудников ИМЭЛ. Е.М. Ярославский также регулярно просил Сталина снять запрет на эту работу. Не дожидаясь разрешения, за день до его 60-летнего юбилея на сталинский стол был положен отпечатанный в типографии экземпляр «Иосиф Виссарионович Сталин (краткая биография)», созданный в ИМЭЛ. Книга имела, по оценке Д. Бранденбергера, «солидную формализированную историю партийной карьеры Сталина» (С. 217). В последнюю неделю 1939 г. книга вышла в твердой обложке (в 1940 г. общий тираж составил 1,2 млн экземпляров). По наблюдению автора монографии, «вопреки официальным ожиданиям, знакомство с революционным путем Сталина не воплощалось автоматически в более широкое чувство советского патриотизма или во внезапно обретенное понимание правильности официального курса. Более того, упоминание в повествовании лишь горстки советских героев и примеров для подражания, похоже, снизило воспитательную роль книги и негативно сказалось на ее способности заинтересовать широкую аудиторию» (С. 217-218). Однако и эта книга, и «Краткий курс» создали набор идейно-политических клише, в которых было принято выражать свое мнение о партии и деятельности Сталина, что свидетельствовало, как отметил Д. Бранденбергер, «о наличии весьма двусмысленной модели общественного восприятия» биографии вождя (С. 218). 
Чрезвычайно показательно в семантическом плане название предпоследней главы рецензируемой монографии - «Окостенение официального курса», что наглядно отражает состояние и идеологической деятельности агитпропа в конце 1930-х гг., и отечественной исторической науки, которой были даны жесткие указания о том, как следует рассматривать историю российского революционного движения и послереволюционного социалистического строительства.

Одиннадцатая глава монографии - «Сталинская массовая культура накануне войны» - посвящена анализу информации множества свидетельств о том, кто и как, с какой целью изучал «Краткий курс». По оценке Д. Бранденбергера, этот «всего лишь учебник» был наделен «каноническим статусом», «непререкаемым авторитетом». Владение «Кратким курсом»как бы давало охранную грамоту, его публичное изучение одновременно являлось и «показателем идейно-политической лояльности», и «почти священнодействием», а умение «воспроизводить наизусть шаблонные фразы и постулаты из книги» признаком высокого уровня овладения политграмотой. Цитирование учебника, как и произведений Ленина и Сталина, становилось обязательным для всех научных и публицистических трудов, указывая на их высокий методологический уровень (С. 219-220, 228-233).

В то же время оказалось, что освоение текста «Краткого курса», якобы рассчитанного на массового читателя, самостоятельно желающего «овладеть большевизмом», доступно лишь партийцам, обладающим высоким уровнем идейно-политической подготовленности и проходящим организованный курс в системе партпросвещения с лекциями по истории, экономике и международным отношениям (С. 221-222). Необходимость приобщения масс к «Краткому курсу» вынудила органы центрального и местного агитпропа заняться изысканием новых методов подготовки лекторов и пропагандистов, обеспечением их дополнительными материалами, облегчающими изучение марксизма-ленинизма.

Принудительные методы идеологической обработки массового общественного сознания на основе «Краткого курса», по наблюдениям Д. Бранденбергера, вызывали недовольство представителей разных профессий и социальных слоев, считавших, что учебник по истории ВКП(б) не поможет им в профессиональном или социальном росте. Такое отношение свидетельствовало о том, что к концу 1930-х гг. явственно обозначились провалы в мобилизационной деятельности агитпропа, что служит подтверждением основной идеи, выдвинутой автором монографии и обозначенной им в заголовке заключения: «Агитпроп в кризисе».

Неизбежное следствие этого кризиса проявилось, по мысли Д. Бранденбергера, в «окостенении» истории партии, приведшем, с одной стороны, к схематичному и безжизненному славословию непогрешимости сталинского руководства как ВКП(б), так и всей советской страной, а с другой - к опасному идейному разоружению советского народа накануне Великой Отечественной войны (С. 253-255).

В этой связи необходимо заметить, что не со всеми утверждениями автора можно согласиться. В частности, о том, что успех в пропаганде официального идеологического курса, достигнутый в середине 1930-х гг., был сорван «большим террором» в конце 1930-х. Однако идеи патриотизма и готовности всеми силами защищать Родину, внедренные в общество во многом благодаря деятельности советской 
творческой интеллигенции и поддержанные агитпропом, не были утеряны: они сохранились и в полной мере проявили себя на полях сражений в период Великой Отечественной войны 1941-1945 гг., выразившись в лозунге «За Родину! За Сталина!», который в общественном сознании являлся олицетворением социализма.

Завершая рецензию, необходимо отметить, что монография Д. Бранденбергера явилась результатом его многолетних и углубленных исследований в области советской идеологической политики, народного образования и массовой культуры. Книга не только дополняет комплекс работ профессора по указанным проблемам, но и имеет самостоятельное научно-познавательное значение, поскольку в ней представлена целостная авторская концепция, рассматривающая эволюцию идейно-пропагандистского аппарата ВКП(б) в связи с воздействием на его деятельность внутриполитических и внешнеполитических событий в межвоенный период.

Автор убедительно показал, что идеологическую деятельность партийного руководства страны направляла исключительно ситуативная необходимость преодоления кризиса, затронувшего систему партпросвещения, а не целенаправленная и заранее продуманная мобилизационная стратегия.

Отметим также, что монография Д. Бранденбергера вносит важный вклад в научное осмысление феномена сталинизма, его практического становления в СССР и укрепления культа Сталина в общественном сознании советских людей в 1930-х гг.

Рецензируемая монография содержит важную методическую составляющую относительно подхода к изучению процесса формирования массового общественного сознания и оценке общественно-политического значения сталинизма, что актуально для авторов, создающих новую научно-исследовательскую и учебную литературу, ориентированную на современную высшую школу России.

Наконец, монография американского профессора представляет значительный историографический интерес, так как идея кризиса сталинского агитпропа противоположна концепции, принятой в отечественной исторической литературе, согласно которой в результате успешной пропаганды ВКП(б) полностью овладела массовым общественным сознанием в СССР.

Научный труд Д. Бранденбергера - человека «со стороны», «с другого берега»- о сталинском агитпропе позволяет по-новому взглянуть на наше «непредсказуемое прошлое», открывает широкие перспективы для его дальнейшего изучения и креативного включения полученных профессором данных в исследования отечественных историков.

Рукопись поступила: 4 декабря 2018 г.

Submitted: 4 December 2018

\section{Информация об авторе / Information about the author}

Георгиева Наталия Георгиевна, доктор Natalia G. Georgieva, Doktor Istoricheskikh исторических наук, профессор кафедры исто- Nauk [Dr. habil. hist.], Professor at the Departрии России Российского университета друж- ment of Russian History, RUDN University. бы народов. 